\title{
SUBSTANTIATION OF DECK PARAMETERS OF ROTARY THRESHING DEVICE
}

\author{
Dmitriy Bakharev, Alexander Pastukhov, Sergey Volvak, Olga Sharaya \\ Belgorod State Agricultural University named after V. Gorin, Russia \\ baharevdn_82@mail.ru,pastukhov_ag@mail.ru,volvak.s@yandex.ru, sharay61@mail.ru
}

\begin{abstract}
The damages of corn grain during threshing depend on many factors, the main of which is timely removal of grain from the threshing chamber what depends on the design of the deck. The functional parameters of the deck in self-propelled combines and stationary threshers used for threshing of seed corn have been studied. Studies of factors affecting the separation process of a mixture consisting of grain and other parts of corn cobs in the threshing chamber were carried out. It has been proved that the shape, size and layout of the deck holes have the greatest impact on the timeliness of the output of the threshed corn grain from the threshing chamber. In this case the deck should consist of three parts of different lengths: 1) a part of the deck of the chamber of the primary damage of the integrity of the cob grain structure; 2) the deck part of the main threshing chamber; 3) the deck part of the finish threshing chamber. The evaluation criteria for choosing the lengths of the deck parts are the average of the double ratio of the linear dimensions of the corn grain of the six main subspecies and the maximum length and diameter of the cobs of 65 main varieties cultivated in Russia. The ratio of the lengths of the first two sections of the deck should correspond to the Fibonacci golden section -1.618 and the double ratio of the linear dimensions of all three sections - 1.29. The studies have evaluated the effect of the shape of the holes: round, round lunate, square, rectangular, and hexagonal. At the same time, the pattern of holes on the hexagon and the square and the square holes, additionally, at an angle $45^{\circ}$ to the rotor axis was studied. The feasibility of using round holes in the deck with a diameter of at least $10 \ldots 14$ mm has been established. As a result of using the deck of the proposed design, the conditions for timely removal of threshed grain from the threshing chamber with a reduced probability of damage are created.
\end{abstract}

Keywords: combine, stationary thresher, rotor, deck, damages of corn grain.

\section{Introduction}

Corn is an important cereal crop ranking third in a production after wheat and rice. The harvesting of corn requires the use of the rotary threshing and separating devices, which are the part of selfpropelled combines or stationary threshing systems. At the present stage of development of science and technology the rotary threshing and separating devices (RTSD) are the most effective for corn threshing. Rostselmash, John Deere, Case, New Holland, Gleaner, Massey Ferguson and other companies use them in self-propelled combines. RTSDs are characterized by high throughput and operating efficiency in a wide range of threshed grain moisture. Like the classic drum systems, RTSD thresh by striking the cobs and pulling them in the gap between the rotor and the deck, as a result of which the grain can receive macro and microdamages. Being on the cob, the grain, which perceives the blows of the rotor, can be pressed into the body of the rod to the $3 \mathrm{~mm}$, which permits to compensate for excessive shock loads and preserve the integrity of the grain during threshing. However, if the grain is separated from the rod, it is deprived of the natural damping system and the rotor blows inevitably lead to its damage, so the grain scraped off the rod must be separated from the total threshing mass as soon as possible and removed from the threshing chamber [1]. In this case, the lower part of the RTSD deck serving as a separator plays an important role. The effectiveness of corn grain separation by RTSD largely depends on the shape, size and number of holes in the trellised deck used.

The producers of RTSD used for corn threshing do not have consensus in this field of concern. John Deere, New Holland and Case combines are equipped with a rod-slatted deck, forming a relief surface with rectangular slit holes [2-4]; Rostselmash Torum, Gleaner and Massey Ferguson combines use a smooth mesh deck with square or rectangular holes [5]. In addition, in the combines of the Rostselmash Torum series the deck rotates in a counter-rotating rotor with a constant frequency of $8 \mathrm{~min}^{-1}$. It is also known that in corn separators, where sieves must be adapted exclusively for this crop, because of the insufficient knowledge of the process round, round well-shaped, square, rectangular and hexagonal holes are applied (Fig. 1).

There is no consensus on the shape, size, number and layout of the holes in the separators of the corn grain in RTSD also. 


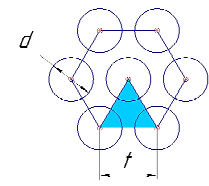

$a$

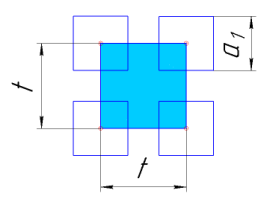

$e$

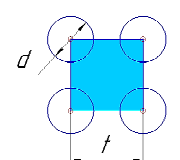

$b$

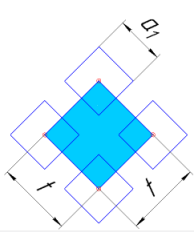

$f$

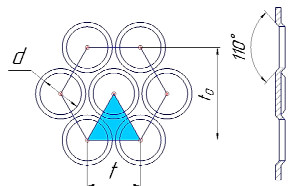

c

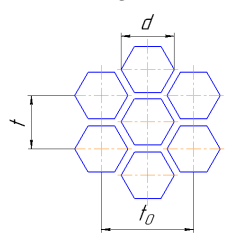

$g$

Fig. 1. Forms of holes in sieves for separation of corn grain: $a$-round holes located on the hexagon; $b$-round holes located on the square; $c$ - round chamfered holes located on the hexagon; $e$ - square hole; $f$ - square hole located at an angle of $45^{\circ} ; g$ - hexagonal hole; $d$-diameter hole, $\mathrm{mm}$; $t, t_{0}-$ step, $\mathrm{mm} ; a_{1}-$ size of the square holes, $\mathrm{mm}$

The purpose of this article is to provide an analytical justification for the dimensional characteristics of the RTSD deck for corn and an experimental testing of evidence-based hypotheses.

\section{Materials and methods}

The research was conducted in accordance with the Federal Scientific and Technical Program for the Development of Agriculture of the Russian Federation for 2017-2025. The process of removing threshed corn from the rotor through the holes in the RTSD deck was studied. An experimental research was carried out with threshing dried to $14 \%$ moisture cobs of dent corn Dar $347 \mathrm{MV}$.

The principles of system analysis of technical objects, methods of searching for analogies for engineering solutions in wildlife, methods of conducting single-factor experiments and statistical processing of experimental data were used while researching.

The experiment was conducted as follows. For 10 seconds $2 \mathrm{~kg}$ of corncobs cleared of leaf wrappers with a moisture content of $14 \%$ were fed (feed is $0.2 \mathrm{~kg} \cdot \mathrm{s}^{-1}$ ) to an experimental RTSD. A multisection bunker was installed under the sieve, in the section of which two trays were fixed to collect the grain with the aim of its subsequent weighing. A rational rotor speed was set at $200 \mathrm{~min}^{-1}$. The experiment was conducted with fivefold repetition. Experimental error is not more than $5 \%$. The mass of grain in trays was weighed on electronic scales.

\section{Results and discussion}

During the threshing process in the threshing chamber of a rotary combine a mixture of whole and partially destroyed kernels is formed, as well as a sheet wrap of cobs. Obviously, the rational size of the deck opening should be such that only grain can easily pass into it. This size is advisable to determine by reference to the calculated particle diameter [6], based on the following reasoning. The grain form of corn of any variety and subspecies can be represented as a pyramid of the height $h$ with a square at the base with the side $m$ (Fig. 2). Based on the condition of geometric similarity of the volumes of the figures, using 3D-modeling, any form of corn grain can be converted into a ball, while maintaining the original volume. Consequently, the calculated grain diameter of corn $d_{c}, \mathrm{~mm}$, is determined from the relation [6]:

$$
\frac{\pi d_{c}^{3}}{6}=\frac{1}{3} \cdot F \cdot h
$$

where $F$ - base area of the pyramid, $\mathrm{mm}^{2}$, then we get

$$
d_{c}=0.86 \cdot \sqrt[3]{F \cdot h}
$$



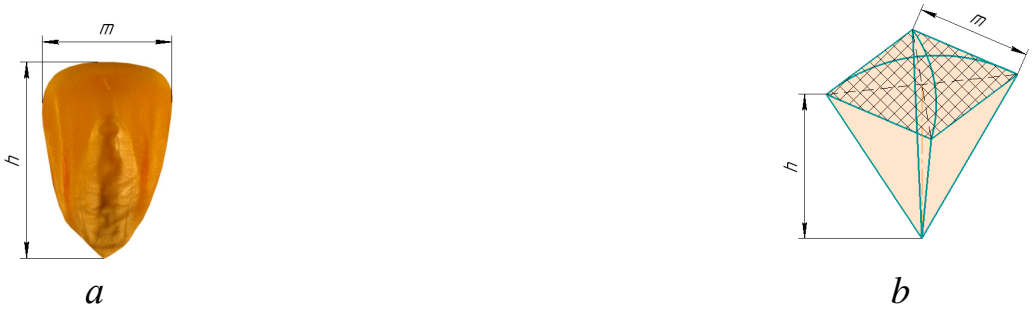

Fig. 2. Parameters for determining calculated grain diameter: $a$ - corn grain; $b$ - grain model

Analysis of 65 main varieties of 6 subspecies of maize cultivated in Russia made it possible to determine the average values of the parameters $m$ and $h$ (Table 1).

Table 1

Average value of the height $h$ and side of the base of the pyramid $m$

\begin{tabular}{|c|c|c|}
\hline Corn Subspecies & $\begin{array}{c}\text { Side of base of the } \\
\text { pyramid, } \mathbf{~ m m}\end{array}$ & $\begin{array}{c}\text { Pyramid height, } \\
\text { mm }\end{array}$ \\
\hline Zea mays L. saccharata Sturt & 9.5 & 7.8 \\
\hline Zea mays L. ceratina Kulesh & 10.3 & 7.8 \\
\hline Zea mays L. indentata Sturt & 8.5 & 11.4 \\
\hline Zea mays L. indurata Sturt & 8.5 & 9.0 \\
\hline Zea mays L. everta Sturt & 5.1 & 7.4 \\
\hline Zea mays L. tunicata Sturt & 6.0 & 5.0 \\
\hline An average for all subspecies & 8.0 & 8.0 \\
\hline Calculated grain diameter of corn & \multicolumn{2}{|c|}{$d_{c}=0.86 \cdot \sqrt[3]{64 \cdot 8.1}=7.0 \mathrm{~mm}}$. \\
\hline
\end{tabular}

Therefore, the minimum size of the holes in the lower part of the deck of the rotary combine that threshes corn should be such that the mass of grains with a calculated diameter of $7 \mathrm{~mm}$ passes freely through the deck without forming arches that prevent the grain from coming out. The formation of vaults in corn grain is excluded, provided that the diameter of the hole in the deck $D$ is at least three calculated grain diameters $d_{c}$, or $D / d_{c} \geq 3$. In this case, $D=21 \mathrm{~mm}$.

When moving a layer of a mixture of grain, rods and sheet wrappers on the surface of the RTSD deck, the grain must move independently downward of the layer and wake up through the holes of the deck subject to minimum resistance conditions. This is facilitated by the use of the relief surface of the sectional bar-slatted deck (Fig. 3), as an additional layer vibration creates. In this regard, smooth decks used in Rostselmash Torum, Gleener and Messi Ferguson combines are less effective.

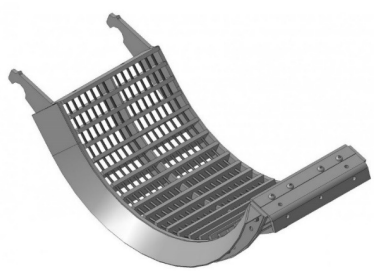

$a$

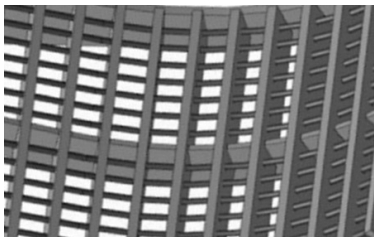

$b$

Fig. 3. Design sections of deck rotary combine harvester: $a$ - deck section; $b$-relief of the internal surface of the deck

The RTSD of combine harvester thresher in most cases includes a mass entry zone, a threshing zone and a separation zone (Fig. 4) [7].

This arrangement of the working bodies of the RTSD has the following disadvantages: 1) the entrance zone does not participate in the threshing process; 2) low transporting ability of the threshing zone leads to an excessively long stay of the threshed mass under the impact of rotor whips, which leads to a large amount of grain damage and undesirable destruction of corncobs; 3) inefficient design of the working bodies in the separation zone requires the use of an autonomous household device, which increases the material consumption of the structure; 4) the lengths of the mentioned above zones are not consistent with each other, although the quality of the RTSD operation as a whole depends on it. 


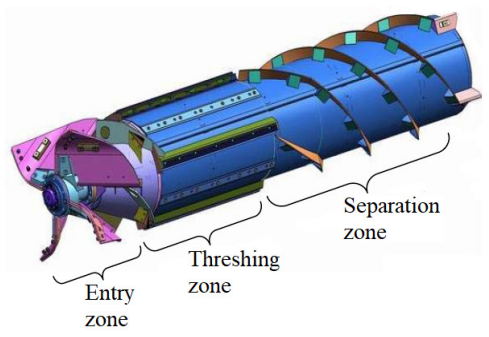

$a$

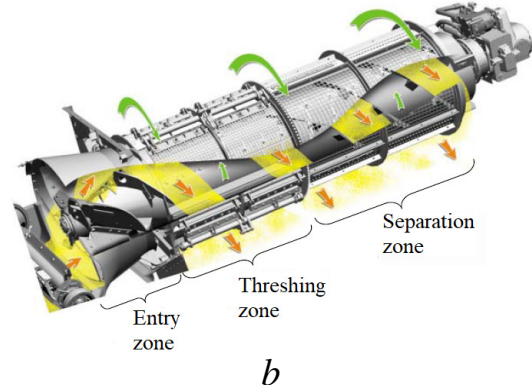

$b$

Fig. 4. Rotary threshing-separating device of combine harvester Rostselmash Torum: $a$ - rotor; $b$ - rotor-deck system

In the case of adaptation for working with corn, the length of the working areas of RTSD is advisable to choose on the basis of the principles of bionics. In accordance with the basics of bionic proportion and the concept of the golden ratio, it can be assumed that, if the length of the separation zone RTSD is taken per unit, $L_{S}=1$, so the threshing zone should be 0.618 of this length $L_{T}=0.618$. Then the sum of the lengths of these zones in relative terms will be 1.618, or the golden ratio of Fibonacci.

The length of the third zone of the $L_{E}$ deck, the entry zone, can be determined from the double ratio of linear dimensions $W[8 ; 9]$ :

$$
W=\frac{\left(L_{S}+L_{T}\right) \cdot\left(L_{T}+L_{E}\right)}{L_{T} \cdot\left(L_{S}+L_{T}+L_{E}\right)} .
$$

The study of the size characteristics of 65 basic varieties of 6 subspecies of corn cultivated in Russia allowed us to establish the total value of their double ratio of linear dimensions equal to $W=1.29$. Then, by analogy with the structure of the cob, knowing the double ratio of the lengths in the working zones of RTSD, one can determine the length of the zone $L_{E}$.

There was constructed a stationary RTSD for threshing corn to test the above assumptions in a practice work (Fig. 5). The layout of the working bodies of the new RTSD involves the following innovations: 1) participation of the $L_{E}$ entrance zone in the threshing process, the primary violation of the cob grain structure is carried out here; 2) combining the threshing zone and $L_{T}+L_{S}=L_{T S}$ separation, what intensifies the process of moving the threshed mass in the threshing process and allows reducing the length of the rotor; 3 ) rejection of the autonomous finish threshing device and the introduction into the single system of the finish threshing zone $L_{F T}$. In accordance with the approach to the ratio of the lengths of the working zones, which is described above, the length of the combined threshing and separation zone of the experimental RTSD is $L_{T S}=700 \mathrm{~mm}$, the entrance zone is $L_{E}=433 \mathrm{~mm}$, and the finish threshing zone is $L_{F T}=250 \mathrm{~mm}$.

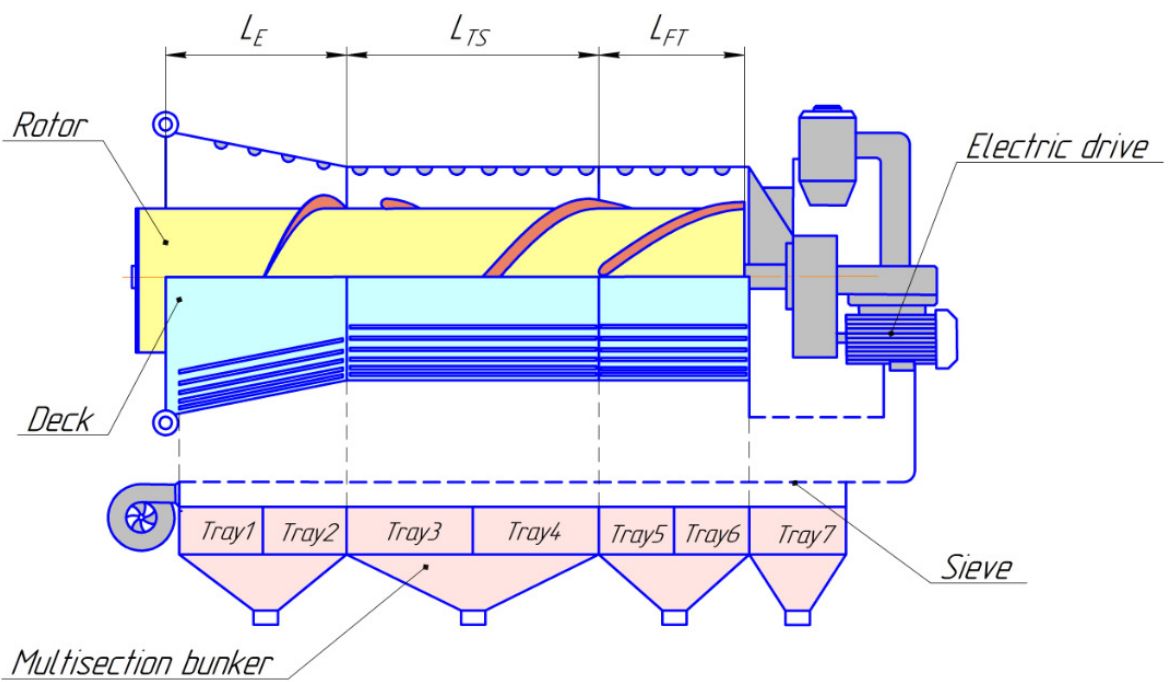

Fig. 5. Experimental rotary threshing-separating device 
Trays 1 and 2 were located in the entrance zone, 3 and $4-$ in the threshing and separation zone, 5 and 6 - in the finish threshing zone and 7 - in the additional section located under the unloading tray for corncobs (Fig. 5). There was an experiment to determine the amount of spilled threshed grain through a smooth or embossed sieve installed in the threshing and $L_{T S}$ separation zone. Therein only a relief sieve was installed in the entrance zone, $L_{E}$ and the finish threshing zone $L_{F T}$. The smooth sieve in the threshing and separation zone $L_{T S}$ is formed by circular holes with a diameter of $21 \mathrm{~mm}$ and the relief zone is formed by rectangular longitudinal slits $14 \mathrm{~mm}$ wide with a chamfer of $3 \times 45^{\circ}$ (Fig. 6). The thickness of the metal, from which the relief deck is made, is $5 \mathrm{~mm}$. A rational rotor speed was set at $200 \mathrm{~min}^{-1}[10 ; 11]$.

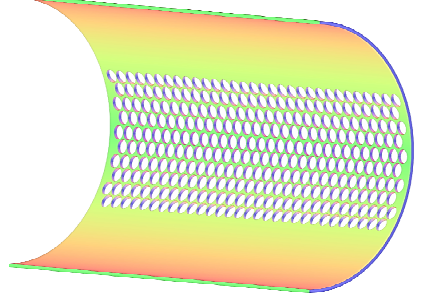

$a$

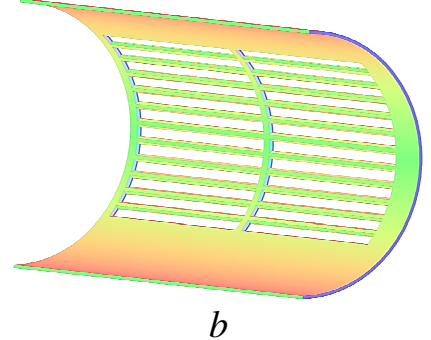

$b$

Fig. 6. Part of deck of experimental rotary threshing-separating device: $a$ - smooth sieve; $b$ - relief sieve

A diagram of distribution of the grain mass among the trays of the sectional hopper RTSD was built based on the average values of the experimental data (Fig. 7).

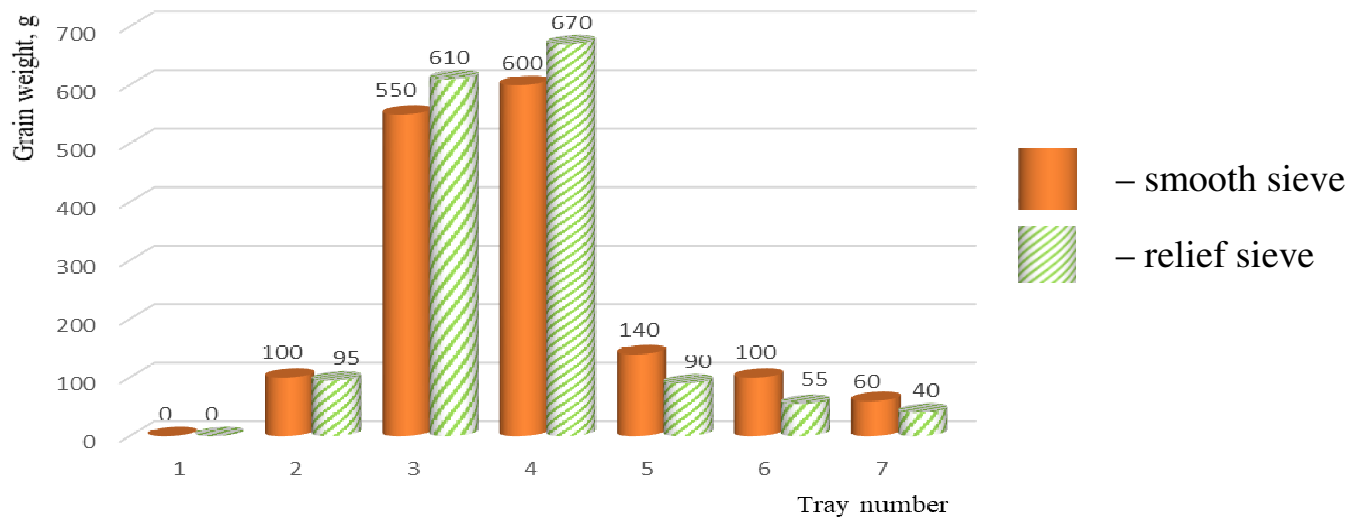

Fig. 7. Diagram of distribution of grain mass in trays of sectional hopper

The use of a relief sieve in the $L_{T S}$ zone, under which the trays 3 and 4 are located, allows to quickly remove the threshed grain from the rotor. In ccomparison with a smooth deck with round holes, the relief deck allows to remove $11 \%$ more grain from the threshing and separating zone $L_{T S}$ and as a result less amount of free grains falls into the finish threshing zone, so that it reduces the likelihood of damage. The increase in the amount of grain spilled through the embossed sieve is explained by the fact that the threshed mass, moving along the embossed sieve, vibrates and this allows the grain to descend as quickly as possible to the periphery of the layer and exit through the slope of the deck. In addition, this vibration eliminates arch formation in the area of the holes in the sieve. The results of the experiment confirm the earlier assumption that it is necessary to reconcile the lengths of the entry, threshing and separation zones, as well as the finish threshing zone.

As one can see from the diagram (Fig. 7), up to $6 \%$ of the threshed grain spills through the holes of the entrance zone; threshing and separation zones - up to $82 \%$; finish threshing zones - up to $9 \%$ and $3 \%$ go as free grains into the discharge opening for the corncobs. As a result of the experiments, it was also established that the index of the underthreshing in RTSD, when using a relief deck, meets the agrotechnical requirements.

Proceeding from the above, the proposed arrangement of the RTSD working areas and the coordination of their lengths allow threshing of corn for high quality without the use of an autonomous finish threshing device. 


\section{Conclusions}

1. In a modern RTSD for threshing corn cobs both in the field and in the threshing floor the deck must be relief, creating by that an additional vibration of the layer in the threshing chamber and facilitating the fastest possible removal of the threshed grain from the impact of the rotor. The relief deck passes through its holes $11 \%$ of free grain more than the smooth one.

2. The relief deck of RTSD should be sectional and cover three zones of the threshing chamber: the entrance zone of threshed mass $L_{E}$, the threshing and separation zone $L_{T S}$, the finish threshing zone $L_{F T}$. The lengths of these zones should be coordinated with each other in accordance with the conditions of the Fibonacci golden ratio $L_{E}+L_{T S}=1.618$ and the double ratio of linear dimensions $W=1.29$.

3. The diameter of the holes in the relief sieve should be such that corn grain with a calculated diameter of $7 \mathrm{~mm}$ passes freely through it without arches forming that prevent the grain escaping. Such conditions are provided, if the deck, made of sheet steel $5 \mathrm{~mm}$ thick, is equipped with slots $14 \mathrm{~mm}$ wide with a chamfer of $3 \times 45^{\circ}$.

4. The use of RTSD of the proposed design in combine harvesters eliminates the use of an autonomous finish threshing device, reducing the complexity and material consumption of the structure as a whole.

\section{References}

[1] Masek J., Kumhala F., Novak P., Fic T. Influence of different trashing system design on grain damage. Proceedings of International Conference "Engineering for Rural Development 2016" May 25-27, 2016, Jelgava. Latvia, pp. 756-761.

[2] Špokas L. Influence of technological parameters of combine harvester «NEW HOLLAND» to grain macro damage. Research papers of IAg Eng LUA \& LU of Ag, 2006, vol 38(2), pp. 27-41.

[3] Li Y., Tao C., Zhe Q., Kehong L., Xiaowei Y., Dandan H., Bingxin Y., Dongyue Z., Dongxing Z. Development and application of mechanized maize harvesters. International Journal of Agricultural and Biological Engineering. Vol. 9 No.3, May 2016, pp. 15-28.

[4] Masek J., Novak P., Jasinskas A. Evaluation of combine harvester operation costs in different working conditions. Proceedings of International Conference "Engineering for Rural Development 2017” May 24-26, 2017, Jelgava. Latvia, pp. 1180-1185.

[5] Fu J., Chen Z., Han L., Ren L. Review of grain threshing theory and technology. International Journal of Agricultural and Biological Engineering. Vol. 11 No.3, May 2018, pp. 12-20.

[6] Богомягких В.А., Несмиян А.Ю. Функционирование бункеров максимального расхода в условиях сводообразующего истечения зерновых материалов: монография. АзовоЧерноморский инженерный институт ФГБОУ ВПО ДГАУ в г. Зернограде, 2015. 179 с. (Bogomyagkih V.A., Nesmiyan A.Y. Functioning of bunkers maximum flow in free-formative conditions of the expiry of grain materials: monograph. The Azov-black sea engineering Institute of FSBEI HVE DSAU in the city of Zernograd, 2015. 179 p.) (In Russian)

[7] Petre I. Miu, Heinz Dieter Kutzbach. Simulation of threshing and separation processes in threshing units. Agrartechnische Forschung 6 (2000) Sonderheft, 2000, pp. 1-6.

[8] Петухов С.В. Биомеханика, бионика и симметрия. М.: Наука, 1981. 240 с. (Petukhov S.V. Biomechanics, bionics and symmetry. M.: Science, 1981. 240 p.) (In Russian)

[9] Bakharev D.N., Pastukhov A.G., Volvak S.F. The concept of bionic design of devices for threshing cobs of maize varietal. ISB-INMA-TEH Agricultural and mechanical engineering. Bucharest 2018. pp. 107-114.

[10]Петунина И.А. Очистка и обмолот початков кукурузы. Краснодар: КубГАУ, 2007. 525 с. (Petunina I. A. Cleaning and threshing corn cobs. Krasnodar: KubSAU, 2007. 525 p.) (In Russian)

[11]Бахарев Д.Н., Вольвак С.Ф., Пастухов А.Г. Бионические основы конструирования молотильно-сепарирующих систем для початков кукурузы: монография. Изд-во ФГБОУ ВО Белгородский ГАУ, п. Майский, 2018. 168 с. (Bakharev D.N., Volvak S.F., Pastukhov A.G. Bionic principles of designing threshing and separating systems for corn cobs: monograph. Publishing House of FSBEI HE Belgorod SAU, Maysky village, 2018. 168 p.) (In Russian) 